\title{
Environmental Responsibility of Multinational Enterprises
}

\author{
Shaoxiong Bai ${ }^{1, \dagger, *}$, Bowei Chang ${ }^{2, \dagger, *}$, Yanfeng Wang ${ }^{3, \dagger, *}$, Yueting Zhao ${ }^{4, \dagger, *}$ \\ ${ }^{1}$ Law School, Central South University, Changsha, 410012, China \\ ${ }^{2}$ School of Law, Chongqing University, Chongqing, 400030, China \\ ${ }^{3}$ College of Social Sciences and International Studies, Law School, University of Exeter, EX4 4QX, UK \\ ${ }^{4}$ Civil, Commercial and Economic Law School, China University of Political science and Law, Beijing, 102249, China \\ "Corresponding author. Email: 18212180331@csu.edu.cn, 2CBW20001228@163.com,30106024@yzpc.edu.cn, \\ ${ }^{4} 180201220 @$ cupl.edu.cn
}

These authors contributed equally

\begin{abstract}
In today's society, MNEs play an increasingly important role in social, cultural, and political issues. MNEs must seize opportunities, invest in development, and obtain the greatest benefits worldwide. To some extent, this is a good thing for the host country. It can develop the national economy. However, on a global scale, as multinational enterprises' production and operation activities continue to cause various environmental pollution phenomena and endanger human physical and mental health, people have begun to realize the importance of environmental pollution. To solve this problem and promote the environmental responsibility of multinational enterprises, this article uses theoretical research methods, case methods, comparative research methods, and historical research methods. Starting from the basic theories of MNEs and environmental responsibility, it analyses the current environmental responsibility of multinational enterprises. And finally, from the international law response of multinational enterprises to environmental pollution, the domestic law response to the environmental pollution of multinational enterprises, and the strengthening of international cooperation. The three aspects provide suggestions to solve how multinational enterprises should assume environmental responsibility. It is proposed that it hopes to clarify the environmental responsibility of MNEs and promote the development of international investment law.
\end{abstract}

Keywords: MNEs, Environmental responsibility, International Investment Law.

\section{INTRODUCTION}

In today's society, MNEs play an increasingly important role in social, cultural, and political issues. MNEs must seize opportunities, invest in the development, and obtain the greatest benefits worldwide. To some extent, this is a good thing for the host country. It can develop the national economy. However, on a global scale, as the production and operation activities of MNEs continue to cause various environmental pollution phenomena and endanger human physical and mental health, people have started to realize the importance of environmental pollution. In this regard, MNEs' active commitment to the environment and responsibilities is of great importance to the world's environmental progress. However, from the current legal point of view, few research results on the environmental responsibility of
MNEs. It can say that if there is no perfect legal supervision system. This will increase the difficulty for MNEs to assume environmental responsibilities and negatively affect human physical and mental health and the development of the world economy. Therefore, this article first discusses MNEs and environmental protection responsibilities from the perspective of international investment law. Starting from the overview of MNEs, we analyze the environmental protection responsibilities of MNEs, including the impact of multinational enterprises' foreign investment on the environment, Environmental responsibility and the constituent elements of environmental responsibility. Secondly, it discusses the status qua of MNEs' environmental responsibility in today's society regarding domestic environmental legislation, international environmental conventions, declarations and guidelines, 
bilateral investment treaties, and free trade agreements. Defects in assuming environmental liability. In response to the research on the above issues, the third author puts forward suggestions on improving the environmental responsibility of multinational enterprises, mainly from the international law response of multinational enterprises to environmental pollution; domestic law responds to the environmental pollution of MNEs and strengthens international cooperation.

\section{MULTINATIONAL ENTERPRISES AND ENVIRONMENTAL PROTECTION RESPONSIBILITY}

Multinational enterprises have long been an indispensable type of enterprise in international economic exchanges. Their means of operation and investment are also very mature. However, many problems will still emerge in the process of their development. Taking environmental issues as an example, there are many disputes in the academic circles, such as the constitutive requirements of environmental responsibility of multinational enterprises, the basis of environmental responsibility of parent companies for subsidiaries, and the imputation principle of environmental tort liability of subsidiaries. The judgment results in judicial practice are also quite different. In this paragraph, the focus of the disputes mentioned above will be summarized and elaborated in the way of listing in combination with cases.

\subsection{Overview of Multinational Enterprises}

In 2010, the world economy (Second Edition) published by Shanghai People's Publishing House pointed that a multinational enterprise refers to an enterprise composed of entities located in two or more countries. These entities use one or several decisionmaking centers to determine their business operations and stipulate the decision-making system, so they have the same business policies and strategic measures [1]. Due to the existence of ownership or other factors, these entities are related to each other, and these entities can influence each other, especially the sharing of technology, resources, and responsibilities with other entities. The structure of a multinational enterprise can usually be divided into branches, subsidiaries, parent companies, and head offices.

\subsection{An overview of Environmental Responsibility of Multinational enterprises}

\subsubsection{The impact of multinational enterprises' foreign investment on the environment}

Multinational enterprises promote the economic development of the host country in the process of foreign investment, but at the same time, they also bring many environmental problems. The reason is that most multinational enterprises established in developing countries will cause serious pollution in the investment process, most of which are heavy industries, which consume a lot of energy in the production process and cause a lot of pollution. There are many reasons for this result. It is not only that multinational enterprises want to reduce operating costs, but more importantly, they can transfer operating risks overseas to avoid harming the country's environment. With the overseas investment of multinational enterprises, the health of the nationals of the host country and the local environment will inevitably suffer varying degrees of damage.

Environmental pollution caused by multinational enterprises in the process of foreign investment has the characteristics of concealment, long-term and discriminatory. Multinational enterprises use foreign investment to build factories in developing countries as host countries to produce highly polluting products. Compared with exporting pollutants to developing countries, this kind of production process that may cause pollution is more concealed in developing countries. , It is difficult to be discovered and paid attention to by the public. Due to the backward economic development level, developing countries hope to develop the economy first and then manage the environment, ignore the damage caused by multinational enterprises to the local environment and blindly pursue economic development. However, the economic development of a country does not happen overnight. There is a longer process, which means that the environmental pollution caused by multinational enterprises will exist for a long time. The pollution caused to the environment is accumulated bit by bit, and the damage to the environment caused by long-term pollution is irreversible. For example, according to the associated press, in the $1870 \mathrm{~s}$, banana workers were infertile due to pesticides, which were harmful to human health and were banned in the United States. However, the Dole Food Company in the United States has been using this harmful insecticide in banana plantations in developing countries for ten years, which eventually led to the infertility of thousands of banana workers. In 1992, La Summers, then chief economist of the World Bank, suggested that the World Bank encourage more dirty industries in less developed countries. The environment has a strong endurance. Even if the polluted environment causes disease, the loss is lower than that of the disease caused by the residents of developed countries. This act of transferring pollution to disadvantaged groups for profit is discriminatory and unethical. 


\subsubsection{The environmental responsibility in multinational enterprises' investment}

As the creators of wealth and accountable for environmental pollution, multinational enterprises must assume more social responsibilities, improve product quality while adhering to the concept of sustainable development of resources and environment, standardizing behavior, and protecting the ecological environment. The environmental protection responsibilities of multinational enterprises include violating laws, regulations, and other relevant provisions in production and business activities, causing environmental pollution and personal health damage. Therefore, they should bear the responsibility for the adverse consequences of domestic laws and regulations and international laws.

\subsubsection{The constitutive elements of multinational enterprises taking environmental responsibility}

First of all, multinational enterprises have environmental infringements in their overseas investment activities. The existence of infringement acts is the basis for the establishment of environmental infringement. As to whether the action must be illegal, the regulations of each country are different. For example, Switzerland's territorial governance capacity and environmental protection standards are recognized in the world. Both officials and citizens have strong environmental awareness. Strict liability is applied in environmental tort in Swiss environmental protection law, but illegality is a necessary condition for tort. At present, in most environmental pollution cases, although the perpetrator has the relevant permit and meets the pollution discharge standards, it still causes serious damage to the victim and the environment. Therefore, it is unreasonable to determine whether an environmental infringement is established only based on illegality. Therefore, even in countries that stipulate that infringements must be illegal, it is common practice to expand interpretations of "illegal nature". It is generally believed that when the infringement exceeds the tolerance limit, it abuses rights and constitutes a violation. It can be seen that judicial interpretations will "Illegality" are expanded to explain, which is more conducive to protecting the rights and interests of victims. In practice, some countries have given up the practice that behavior must be illegal. For example, when persecuted by the environment in Germany, victims abandon the illegality of the behavior and directly seek relief. Service facilities to comply with administrative principles and other standards of public law does not exempt from responsibility.

Second, environmental infringement of a multinational enterprise must result in damage. Generally speaking, most of the components of infringement must have the occurrence of damage. Still, for environmental infringement, as long as the act has the possibility of causing environmental damage, the occurrence of actual harm is not necessary. Suppose the actual harm result is a vital element of environmental infringement. In that case, the impending environmental damage cannot be prevented in advance, but relief and compensation can only be provided after the accident occurs. This kind of remedy is not able to protect the rights and interests of the victims. In essence, it cannot solve the problem of environmental pollution.

Third, there is a causal relationship between environmental torts and the consequences of ruin. The establishment and improvement of a strict liability system have strengthened the protection of victims and the environment. However, if the victims want to obtain compensation, they still need to break through a barrier: the court's determination of the cause and effect between the tort and the consequence of the damage. However, due to the particularity of environmental torts, courts were very reluctant to accept the environmental responsibility aspect of investment arbitration in early arbitrations. For example, in Santa Elena v. Costa Rica, Costa Rica expropriated the investor's land by expanding the border of the national park, believing that this would protect the stability of the animal population. When confirming the amount of compensation received for the investment, the court held that the property collected for the environmental purpose did not change the legal nature of obtaining appropriate compensation.

\subsection{The imputation principle of a subsidiary's environmental tort liability}

The imputation principle of the environmental responsibility of the subsidiary refers to the fact that the actor's behavior causes damage to others, according to which judgment criteria the actor is required to bear the responsibility. Nowadays, the common imputation of various countries. There are several principles:

The principle of fault liability is the basic principle of general infringement and whether there is a fault in one of the conditions for determining the actor's responsibility. However, placing this principle in environmental infringement by multinational enterprises will expose many defects of this principle. First, in foreign investment and management, it is much more difficult to determine the environmental violations of multinational enterprises. In countries with low environmental standards or imperfect environmental systems, investment is the first choice of many large companies, and multinational enterprises are no exception. They try to evade the regulations of their home countries. Second, in foreign investment, multinational enterprises will also use different standards of technology and use the protection of communal technology secrets as an excuse to reject investigations into the causal 
relationship between infringement and damage. Therefore, in situations where environmental damage occurs frequently, victims cannot get timely relief based on this principle, which runs counter to the original intention of protecting the environment.

No-fault liability means that no matter whether the perpetrator is at fault for the occurrence of the consequences of the damage, it should bear the responsibility. The purpose of establishing this principle makes up for the loss of the victim, not to sanction the offender. As far as environmental infringement is concerned, illegality is no longer a necessary element. However, if the discharge of pollutants causes damage to the environment, you still have to bear the responsibility for compensation. This is the implementation of the principle of no-fault liability in the environmental field. When the perpetrator is held accountable for environmental protection following per under the Tort Liability Law, civil law countries usually apply strict liability.

Fair responsibility is a fair concept. Both parties are subjectively not at fault for the occurrence of damage, but when other principles cannot be applied by following per under the law, both parties' property losses and economic conditions shall be comprehensively considered. Give appropriate compensation to the victim. In real life, all infringement cases do not necessarily have an accountable subject, and accidents also occur from time to time.

It can be seen from this that when the law has a clear stipulation on which principle of the rule to apply to a certain infringement case, it must be by following per under the law. The application of the principle of fairness cannot be arbitrarily expanded.

It can be observed that in terms of assuming environmental responsibilities, the entities of multinational enterprises should not follow one imputation principle invariably but should analyze different cases and apply different imputation principles.

\section{THE CURRENT SITUATION OF MENS' ENVIRONMENTAL RESPONSIBILITY}

In the previous part, the basic theory and imputation principle of MNEs' environmental responsibility are expounded. It can be seen that the theory of environmental responsibility has been quite mature. Still, there is a huge difference between theory and reality in real life, which leads to the current situation of MNEs' environmental responsibility is not optimistic. This issue will be explained in two parts: The legal regulation and the defects.

\subsection{The legal regulation of MNEs' environmental responsibility}

To study the current regulation of MNEs' environmental responsibility, it is necessary to have a sufficient understanding of the worldwide consensus on environmental responsibility, the governmental rules or laws on MNEs' environmental responsibility in different countries. The worldwide consensus, governmental rules, and law are included as the sources of law, which refers to the effective legal regulation formulated by the recognized legislature and promulgated by and the law declaring organ. It usually exists in written form, representing the official attitude of a country or region to a certain matter.

There are three main sources of law of MNEs' environmental responsibility: domestic environmental legal norms, international environmental conventions, declarations and guidelines, environmental clauses of Bilateral Investment Treaty, and Free Trade Agreement. Domestic environmental legal norms are the main forms of sources of law, but the business scope of multinational enterprise involves multiple countries. It is obvious that the adjustment of domestic laws alone cannot carry out effective supervision. Collaboration between countries can be described as an alternative path.

\subsubsection{Domestic environmental legal norms}

Domestic environmental legal norms refer to the legal documents made by the legislature to regulate the relationship between humans and the environment. It is mainly for the protection of natural resources and restrictions on the use of natural resources. Domestic environmental legal norms are mainly divided into governmental rules and laws. Each country has its environmental legal norms, and they are effective for multinational enterprises. The most common form of domestic environmental legal norms is environmental protection law, which is the law to promote the sustainable development of the economy and society.

\subsubsection{International environmental conventions, declarations and guidelines}

From the second half of the nineteenth world, more countries pay attention to environmental protection, modern international environmental law gradually formed a system. Its development can be roughly divided into four stages. From the middle of the 19th century to the founding of the United Nations in 1945 was the embryonic stage of modern international environmental law. From 1945 to the United Nations Conference on human environment in Stockholm in 1972 was the second stage. At this stage, modern international environmental law was initially formed. In the following 20 years, until the United Nations Conference on 
Environment and Development held in 1992, modern international environmental law was in a period of continuous vigorous development. Finally, from 1992 to now, modern international environmental law has been basically mature [2]. So far, there are more than one hundred international conventions and declarations related to the environment in the world. Moreover, there are some non-legally binding guidelines. For example, the Ten Principles of the UN Global Compact includes three basic principles of corporate environmental responsibility.

\subsubsection{Environmental clauses of Bilateral Investment Treaty and Free Trade Agreement}

Bilateral Investment Treaty (BIT) refers to the bilateral treaties concluded between the two countries to protect the international investment. In recent years, with the development of international trade, BIT has become the most important international law system to protect investment. The investment of multinational enterprises will bring a series of environmental problems to host countries. Therefore, some countries choose to add environmental clauses in BIT. For example, Article 10 of the Agreement between the government of the people's Republic of China and the government of the United Republic of Tanzania on the promotion and mutual protection of investment stipulates that: The Contracting Parties recognize that it is inappropriate to encourage investment by relaxing domestic health, safety or environmental measures. Accordingly, a Contracting Party should not waive or otherwise derogate from, or offer to waive or otherwise derogate from, such measures as an encouragement for the establishment, acquisition, expansion, or retention in its territory of an investment of an investor.

Free Trade Agreement (FTA) is a legally binding contract between two or more countries, aiming to promote economic integration. Its goal is to eliminate trade barriers and allow products and services to flow freely between countries. Environmental issues are usually stipulated in free trade agreements as important clauses. A case in point is North American Agreement on Environmental Cooperation (NAAEC), which is the Supplement to the North American Free Trade Agreement [3]. Its essence is to place the formulation and implementation of the Contracting States' environmental laws, policies, and standards under the international supervision of the sub-agreement arrangement. To ensure the effective implementation of the Contracting States' environmental laws, maintain a high level of the environment while expanding trade, and cooperate to prevent transnational environmental hazards.

All in all, the domestic environmental legal norms, the international environmental conventions, declarations and guidelines, and the environmental clauses of Bilateral Investment Treaties and Free Trade
Agreements all regulate and restrict the environmental responsibility of multinational enterprises. However, it seems that the provisions on the environmental responsibility of multinational enterprises are not binding enough, which is difficult to operate in practice.

\subsection{The defects of MNEs' environmental responsibility}

\subsubsection{The lack of the force of legal regulations}

In terms of domestic legislation, the legislation of developed countries on MNEs' environmental responsibility is relatively comprehensive. However, the environmental legislation of developing countries is relatively simple. The provisions on MNEs' environmental responsibility are relatively few, the provisions are lack force, and the part of legal responsibility is insufficient. In many countries, environmental protection legal regulations have always been at the theoretical level, which is difficult to be applied to practical operations.

Since the 1990s, the international community has formulated various norms on environmental protection. These norms have shown a diversified trend. There are not only principles and declarations for environmental protection but also legally binding regulations applicable to the contracting parties to International environmental conventions and non-legally binding guidelines. These international rules play an important role in restricting the behavior of multinational enterprises, but most of them are advocacy documents and only have lax laws. Even if violated, there are no serious penal consequences, which encourage multinational enterprises to indulge in their actions. They only provide guidance for multinational enterprises to undertake ecological and environmental protection responsibility. For example, the "Code of Conduct for Multinational enterprises" has a wide range of applications, strong comprehensiveness, and comprehensive content coverage, covering almost all aspects of multinational enterprises. However, when it comes to environmental aspects, it only requires multinational enterprises to treat the environmental management system as continuously established and improved, and the impact of the production process on the environment and human health is assessed promptly. At the same time, it is also under an obligation to disclose its business activities in a timely and true manner and accept public supervision [4]. It is not difficult to see that the international community has taken some measures against multinational enterprises and their activities. They have remained at the theoretical level and are difficult to apply to practical operations. Therefore, there are still obvious deficiencies in both the institutional and theoretical levels.

In the case of Chevron Corp v., the Republic of Ecuador, the low effect of environmental law leads to the 
slow process of litigation. In other words, the force of the legal regulations is insufficient. It made the case continue for several tens of years.

\subsubsection{The lack of cooperative supervision between sovereign states}

The strength of developed and developing countries is not equal. The economic strengths of developed countries and developing countries are very different, so they are also unique in many aspects. As far as the supervision of environmental issues is concerned, it is clear that developed countries have a relatively comprehensive environmental legal system and are more than adequate to deal with increasingly complex environmental issues. This is also one reason for higher environmental standards for multinational enterprises in developed countries, such as the higher market entry barriers for enterprises. However, the developing countries lag behind the developed countries in many aspects, and the establishment process of the environmental legal system is relatively slow. Therefore, there is a big power gap between sovereign states. It leads to the lack of cooperation and mutual supervision of the prerequisite - - equal status, making it difficult for sovereign states to achieve environmental cooperation. It then leads to the long-term defects of multinational enterprises' environmental responsibility.

There are three main reasons for the lack of cooperative supervision between sovereign states.

Firstly, developing countries are at a disadvantage in the negotiation of the agreement. In terms of the level of legislation or the sense of participation in the formulation of international rules, developed countries are the first movers. As far as the relevant regulations on environmental responsibility are concerned, European and American countries have been involved in the legislation for a long time. The developed countries themselves have a strong professional legislative capacity, while the developing countries are relatively inexperienced. Therefore, the developing countries are at a disadvantage in the cooperation of international environmental responsibility governance. Besides, in formulating international rules, developed countries have an extremely strong voice and high reputation, resulting in minimal participation of developing countries. In the GATS and trims trade agreement, many suggestions made by developing countries have not been adopted, and no measures have been taken to solve the environmental and other social problems caused by the foreign investment of multinational enterprises.

Secondly, to pursue better cooperation, agreements signed by developing countries rarely designs environmental protection clauses. Compared with developed countries, developing countries have abundant labor resources and low land prices, which are favored by developed countries. At the same time, for developing countries to express their determination to attract foreign investment and obtain more large-scale overseas investment, they often give huge preferential policies to large multinational enterprises to attract foreign investment. For example, tax reduction or exemption, preferential land prices [5]. Some developing countries rely on multinational enterprises to achieve rapid national development, thereby lowering the corresponding regulatory standards. The requirements of the enterprises' actions are relatively muted at the same time. Therefore, many countries choose not to stipulate the environmental responsibility of multinational enterprises in cooperation agreements or domestic legislation.

Finally, it is difficult to unify the opinions of developed and developing countries. When a country conducts related activities, it generally puts its interests first, so it is difficult for a sovereign country to transfer part of the right when conducting international cooperation. This is also the difficulty between countries for cooperation [6]. Therefore, in the formulation of international rules and bilateral and multilateral investment agreements, it is difficult for the two countries to reach an agreement, whether between developed or developing countries or between developed and developing countries.

According to the official data of the Ministry of Commerce of China, as of January 1, 2018, China has signed Bilateral Investment Treaties with 132 countries and regions. Still, these treaties contain almost no environmental protection provisions. This has an important relationship with the above three reasons. In particular, China is in a critical period of rapid development. To develop its economy, China has sacrificed part of the ecological environment.

In international investment, the most common way to determine the environmental damage liability of MNEs is litigation, followed by mediation and arbitration. But the lack of MNEs' environmental responsibility legal regulations slows down the process of litigation. Therefore, in international investment, the environmental responsibility of multinational enterprises needs to be improved immediately.

\section{THE LEGAL PERFECTION OF ENVIRONMENTAL RESPONSIBILITY OF MULTINATIONAL ENTERPRISES IN INTERNATIONAL INVESTMENT}

\subsection{International law responses to environmental pollution by multinational enterprises}

In recent years, environmental protection in IIAs has become a common practice among leading countries. Of the 42 IIAs concluded since 2015 collected by UNCTAD, 
15 refer to the host country's right to regulate in the preamble, 23 refer to sustainable development, and 15 refer to environmental aspects. In the body of the treaty, 36 countries refer to the environment, 13 refer to the right to regulate or use similar concepts, 19 refer to corporate social responsibility, 23 refer to the obligation not to lower environmental standards, and 20 include environmental exceptions in their general public policy exceptions. Display equations should be flush left and numbered consecutively, with equation numbers in parentheses and flush right. First, use the equation editor to create the equation. Then, select the equation, and set the "Equation" Style. Press the tab key and type the equation number in parentheses [7].

Although many agreements mention contents about environmental protection, most of them are vague. With little clarity on the specific criteria for ecological damage caused by multinational enterprises, multinational enterprises' particular responsibilities should bear, and the ways of relief after environmental damage. Some of the treaties are not binding in practice but only serve the function of guiding initiatives. As a result, it is often difficult for these treaties to effectively address environmental damage caused by MNEs in practice. And, in international environmental protection issues, due to the nature of the environment, preventive acts are more important than punitive ones [8]. So it requires us to strengthen international legislation to effectively curb the environmental pollution problems of multinational enterprises from a global perspective.

On the one hand, we need to increase the number and clarify the status of environmental protection provisions in international investment agreements. If environmental damage is to be regulated, then there need to be laws that can hold it. Although environmental protection provisions have been increasing in recent years, they are still far from adequate in terms of number and content. We, therefore, need to increase the number of IIAs and encourage countries to negotiate IIAs that include environmental provisions. At the same time, these environmental provisions should be as binding as other provisions. And if there is a conflict of treaty application between environmental provisions and other provisions, we should prioritize environmental conditions while respecting sovereignty.

On the other hand, the content of the agreement should be clear and specific. Firstly, there should be a clear definition, classification, and criteria for environmental pollution by multinational enterprises to effectively deal with the actual problem. Secondly, the provisions should stipulate the obligations of multinational enterprises to protect the environment and the tort liability for environmental damage caused by the breach of these obligations. The provisions could further clarify the forms of liability, i.e., fault, no-fault or equitable liability. In fact, given the irreversible nature of environmental damage and the high risk of certain production activities of multinational enterprises, we believe that the form of liability should be a mainly nofault liability, supplemented by fault liability. Finally, given the seriousness of the environmental damage, the agreement needs to give clear avenues of redress to the victims, the host country, who have suffered damage due to the actions of multinational enterprises.

\subsection{Domestic law responses to environmental pollution by multinational enterprises}

In terms of domestic law, relevant environmental legal systems should be actively improved, including a system of environmental standards for multinational enterprises, an environmental access system, an environmental liability insurance system, and an environmental protection payment system.

Developing countries, as host countries, often lower domestic environmental standards or do not restrict foreign investment in highly polluting industries to attract foreign investment. Due to the different levels of economic development in each country, it is unrealistic to require the same environmental standards for each country. Still, it is the common responsibility of each entity to protect the environment in which we live. Therefore, firstly, developing countries should set environmental standards according to their level of development and not lower them arbitrarily. At the same time, the host country can, through some preferential policies, prompt and encourage multinational enterprises to adopt higher standards of the home country to reduce the risk of environmental pollution as much as possible.

Secondly, developing countries can achieve control over environmental pollution by MNEs by restricting their investment practices. The host country may set up a market access regime for some highly polluting industries and not open up these industry areas to the outside world. At the same time, the host country can also restrict the number of foreign investments in these sectors or limit the number of foreign investors in these sectors through administrative permits.

Thirdly, host countries can also make special legal provisions for some highly polluting enterprises. Suppose a multinational enterprise is a pollutionintensive enterprise when making a cross-border investment. It may be required to deposit a certain amount of environmental protection deposit depending on the level of potential environmental threat. If a multinational enterprise violates the relevant provisions of the environmental protection clause in the investment agreement, its deposit will be forfeited. However, the deposit will be refunded in installments if the multinational meets the basic environmental responsibility requirements of the host country within a certain period [9]. On the other hand, environmental 
liability insurance could be mandatory in some environmentally high-risk sectors. Host country laws can require multinational enterprises to take out insurance when investing in environmentally high-risk areas. So, the host country can receive a certain amount of compensation when the multinational enterprises' business practices produce environmentally damaging results. This makes up for the multinational enterprises' lack of funds. At the same time, for multinational enterprises, the premium payment is closely related to their specific operating conditions. So the liability insurance system will also encourage them to adopt hightech environmental protection technology and equipment to reduce pollution and improve the efficiency of resource use to reduce the corresponding premium payment, to achieve a positive cycle of environmental management [10].

\subsection{Strengthening international cooperation}

Environmental pollution by multinational enterprises is harmful on a global scale, and investment agreements are in some cases not binding. Therefore, it is still difficult to fully solve this problem by merely enacting laws, so it is necessary to enhance international cooperation to promote the implementation of the laws.

In this regard, we should first pay attention to giving full play to the role of the United Nations, various other international organizations, and non-governmental organizations, uniting international efforts to ensure the implementation of treaties and facilitate the settlement of disputes.

It is also necessary to strengthen cooperation between countries, thereby preventing home countries from harboring multinational enterprises in violation of the law and ensuring the treaty's implementation, such as establishing an environmental protection fund system. When an investment agreement enters into force, the parties can subscribe a certain amount of money to the environmental protection fund and agree on a certain period for payment [11]. The fund should be used for emergency relief funds for environmental damage. After environmental damage in the host country, the host country can claim compensation from this fund after the right to redress has been exhausted. After environmental damage has occurred, the home country of the multinational enterprise shall recover the total amount of the relief funds paid by the fund from the multinational enterprise. And the home country shall be jointly and severally liable to the multinational enterprise for the full amount of the fund if it has not exercised its rights.

\section{CONCLUSION}

MNEs play a major role in the process of economic globalization, and their foreign investment operations play an important role in the development of the global economy. Although the investment of multinational enterprises has brought progress to the host country's economy, we should also pay attention to a series of serious environmental pollution accidents that occurred in the process of foreign investment by multinational enterprises. This caused huge losses to the resources of the host country and caused irreversible pollution to the environment, posing a huge threat to the health and safety of the citizens of the host country. These serious environmental pollution accidents remind people to focus on the problems that multinational enterprises may bring when investing abroad. Therefore, to solve this problem, this article focuses on the environmental protection responsibilities of MNEs. They are studying the impact of MNEs' foreign investment on the environment and studying the environmental responsibilities of foreign investment and the constituent elements of environmental responsibility. On this basis above, the author analyzes the status qua and predicament of multinational enterprises' environmental responsibility from domestic and international legislation, which is very important for studying the issue of multinational enterprises' environmental responsibility. Finally, this article puts forward suggestions on improving the environmental responsibility of multinational enterprises. It discusses the international law response of multinational enterprises to environmental pollution, the domestic law response to environmental pollution of multinational enterprises, and the strengthening of international cooperation. It provides new ideas and development directions for solving the problem of multinational enterprises assuming environmental liability.

\section{REFERENCES}

[1] Y. Zhang, D. Sun, M. Yang, The world economy Second Edition. Shanghai, 2010.

[2] R. Falkner, Global Environmental Responsibility in International Society, The Rise of Responsibility in World Politics. 01(2020) 21-23.

[3] L. Yao, One belt, one road initiative, multinational enterprises' environmental responsibility in international investment. Beijing, 2018.

[4] C. Voigt, International Environmental Responsibility and Liability, (2021)41-42. DOI: http://papers.ssrn.com

[5] L. He, On the regulation of environmental responsibility of multinational enterprises in China, GX. (2019) 182-183

[6] Y. Huang, International legal regulation of environmental responsibility of Multinational enterprises, CE. (2018) 188-189 
[7] X. Han, Environmental protection issues of China's overseas investment--an examination based on the dimension of investment law, Journal of Xiamen University (Philosophy and Social Science Edition). 03(2018) 148-159

[8] Z. Ma, L. Hu, On the international legal regulation of multinational enterprises' investment environmental responsibility, Strait Law 47, 55(2020) 57-58

[9] L. Zhang, Research on the Legal Issues of Pollution Transfer by Multinational enterprises, China University of Political Science and Law. 02(2007) 25-27

[10] Z. Chen, Research on Environmental Responsibility of Multinational enterprises, Jilin University. 05(2014) 2-3

[11] M. Wang, Research on the Regulation of Environmental Liability of Multinational enterprises, Shanghai University. 03(2015) 13-15 